\title{
Histeria masculina: Os impasses na assunção da posição sexual
}

\section{Male hysteria: The impasses in take on the sexual position \\ Histeria masculina: Los impasses en asumir la posición sexual}

\author{
Jéssica Fernanda Matias*
}

Universidade Federal de Minas Gerais - UFMG, Belo Horizonte, Minas Gerais, Brasil

\begin{abstract}
RESUMO
Dada a associação histórica da histeria com a mulher e sua relação com o feminino, muitos trabalhos buscam compreender os atravessamentos dessa posição subjetiva para a sexualidade da mulher. O presente artigo promove a urgência em discutir as implicações de sua incidência sobre os homens, anatomicamente falando. Sendo assim, visa discutir os efeitos da dinâmica da histeria para o homem, no que concerne à assunção da posição sexual. Para tanto, se tratando de uma pesquisa teórica, partiremos de um rastreamento dos textos de Freud e do primeiro ensino de Lacan, buscando referências sobre a histeria masculina e, sobretudo, considerações sobre casos de homens histéricos. Posteriormente, articularemos os aspectos destacados pelos autores com o que, na teoria psicanalítica, se apresenta como particular à posição masculina, tal como a relação com o significante falo, com a castração e a identificação simbólica, bem como os efeitos disso na dinâmica do desejo e da fantasia.
\end{abstract}

Palavras-chave: histeria masculina, Complexo de Édipo, posição sexual, castração.

\begin{abstract}
Given the historical association of hysteria with women and their relation to the feminine, many papers seek to understand the difficulty of this subjective position for women's sexuality. The present article promotes the urgency to discuss the implications of its incidence on men, anatomically speaking. Thus, this work aims to discuss the effects of the dynamics of hysteria for men, in its concerns to the sexual position assumption. For this, as it is a theoretical research, we will start with a screening of Freud's and Lacan's first period of teaching texts, looking for references of masculine hysteria and, mainly, considerations on cases of hysterical men. Subsequently, we will articulate the aspects highlighted by the authors, with which, in psychoanalytic theory, is presented as particular to the masculine position, such as the relation with the signifier phallus, with castration and symbolic identification, as well as its effects in the dynamics of the desire and fantasy.
\end{abstract}

Keywords: male hysteria, Oedipus complex, sexual position, castration. 


\begin{abstract}
RESUMEN
Dada la asociación histórica de la histeria con la mujer y su relación con lo femenino, muchos trabajos buscan comprender los atravesamientos de esa posición subjetiva para la sexualidad de la mujer. El presente artículo, promueve la urgencia en discutir las implicaciones de su incidencia sobre los hombres, anatómicamente hablando. Por lo tanto, este trabajo trata de discutir los efectos de la dinámica de la histeria para el hombre, en lo que concierne a la asunción de la posición sexual. Para ello, si se trata de una investigación teórica, partiremos de un rastreo de los textos de Freud y de la primera enseñanza de Lacan, buscando referencias sobre la histeria masculina y, sobre todo, consideraciones sobre casos de hombres histéricos. En la teoría psicoanalítica, se presenta como particular a la posición masculina, tal como la relación con el significante falo, con la castración y la identificación simbólica, así como los efectos de ello en la dinámica del hombre, el deseo y la fantasía.
\end{abstract}

Palabras-clave: histeria masculina, Complejo de Edipo, posición sexual, castración.

Dada às vicissitudes da sexualidade humana, Freud (1996a/1905/), continuamente, preocupou-se com o que ele chamou de "variação da vida sexual normal". Especialmente na neurose, o psicanalista afirma que na vida de todos esses sujeitos é possível encontrar moções de inversão e até mesmo fixação libidinal em pessoas do mesmo sexo. 0 autor destaca que, a despeito de todo o cuidado que se deve ter na investigação para apreciar adequadamente a importância desses fatores na configuração de um quadro clínico, só se pode "asseverar que a tendência inconsciente para a inversão nunca está ausente e, em particular, presta os maiores serviços ao esclarecimento da histeria masculina" (p.157). Proposições como essa se repetem em várias passagens em que o pai da psicanálise faz menção ao quadro da histeria masculina. Também Lacan (2007/1977), no final de seu ensino, em "Considerações sobre a histeria", assinala que a respeito do "histérico macho? Não se encontra um que não seja fêmea" ( $p$. 17).

Nessa mesma direção, autores, como Nasio (1991), o qual não considera a existência de uma histeria em homens diferente do que seria a histeria na mulher, ressalta que a própria expressão 'histeria masculina', muito utilizada, inclusive, por Freud, denota uma contradição, "pois o substantivo histeria significa incerteza sexual (nem homem, nem mulher), enquanto o adjetivo masculino, ao contrário, é decisivo e faz uma escolha onde a escolha se revela impossível" (p. 66).

Desse modo, a discussão, a respeito da histeria e o conflito com a sexualidade, é preponderante, sobretudo, no campo da psicanálise, no que tange a relação da mulher com a feminilidade. Conforme Safatle (2016, p. 381), "há um problema ligado à assunção da feminilidade que assombra a histeria". De tal modo, o autor reitera 
que "é impossível à histérica lidar com os desafios próprios a toda e qualquer mulher que se sustenta na posição feminina" (p. 381). Este artigo, que se refere a uma pesquisa de mestrado, busca, então, discutir os efeitos dessa posição subjetiva para o homem, ou seja, para o sujeito que ao se fazer existir busca fazê-lo a partir da percepção de si próprio enquanto portador dos caracteres biológicos e sociais da masculinidade.

Tratando-se de uma investigação teórica, partimos de um rastreamento na literatura psicanalítica para assinalarmos quais elementos se destacam, na abordagem e nas considerações realizadas pelos autores, a respeito da dinâmica intersubjetiva dos homens e/ou personagens os quais atribuíram uma possível relação com a histeria. Bruno (1986), ao tratar deste assunto, considera que na clínica freudiana a histeria masculina seria uma questão clássica se não fosse pela ausência de um caso paradigmático, ou seja, uma situação clínica incontestável e a relativa marginalidade de sua abordagem na literatura analítica. No ensino de Lacan, a clínica sobre a histeria masculina é ainda mais difícil de ser avaliada, uma vez que - esforço do psicanalista francês, para além de estabelecer diagnóstico e justificá-lo, se concentrou em elucidar a histeria em relação ao ato, à transferência, à ciência e ao discurso. Todavia, encontramos subsídio para esta discussão, sobretudo, quando Lacan aborda a causalidade significante da histeria, ressaltando as dificuldades no acesso ao recurso simbólico do falo, bem como quando compreende a histeria a partir de uma questão estrutural, sintetizada na interrogação sobre "O que é uma mulher?". (Lacan, 2002/1955-56)

\section{Um breve rastreamento sobre a histeria masculina em Freud}

O interesse de Freud pela histeria masculina surge no início de seus estudos com Charcot. Assim, ainda nos trabalhos pré-psicanalíticos, apresenta à Sociedade de Medicina de Viena um artigo, não publicado, intitulado Uber mannlichehysterie - Sobre a histeria masculina. Apesar da má repercussão do texto, Freud (1925/1996b) é desafiado a apresentar um caso que confirmasse suas proposições. Com efeito, suas primeiras formulações publicadas sobre o assunto se encontram no relato do caso de August P., descrito no texto "Observação de um caso grave de hemianestesia em um homem histérico" (Freud, 1996c/1886), no qual, apesar de poucos fatores psicológicos relatados, 0 autor conclui algo para além do acometimento orgânico e estabelece o diagnóstico de histeria que, naquele momento, firmava-se nas influências de Charcot, semelhante ao que situara no texto "Histeria" (1888). Neste texto, Freud (1996d/1888) assinala que os homens jovens são suscetíveis à 
histeria devido aos traumas e intoxicações. Para o autor "A histeria masculina tem a aparência de uma doença grave; os sintomas que produz são quase sempre pertinazes; a doença, em homens, de vez que tem a importância maior de provocar uma interrupção do trabalho, tem também maior importância prática" (p. 89).

Após as primeiras formulações, Freud iniciou importantes modificações em suas ideias que culminaram na concepção da psicanálise, quando a histeria tem sua origem explicada pela passividade frente a uma experiência sexual precoce e traumática, ligada à prática de sedução e ação de um agente. Com essa concepção, a predominância desta neurose em mulheres é atribuída ao comportamento sexual naturalmente passivo das mesmas, mas Freud (1996e/1896) assinala que ainda nos homens histéricos a passividade sexual se evidenciava. Isso implica dizer que a histeria envolveria, ao contrário da neurose obsessiva, "uma experiência à qual alguém se submeteu com indiferença ou com um pequeno grau de aborrecimento ou medo" (Freud, 1996e/1896, p. 154). Posteriormente, mesmo abandonando este ponto de vista conclusivo, - psicanalista ressalta que, de alguma maneira, a correlação observada entre passividade/ histeria e atividade/ neurose obsessiva deveria ser mantida.

Ao constatar a noção de realidade psíquica e a existência de uma sexualidade infantil inerente ao desenvolvimento, Freud passa a considerar que a referida experiência de sedução poderia envolver uma fantasia criada pela própria criança. A neurose histérica resultaria de um movimento de defesa, denominado recalque Verdrangung -, o qual resistiria às representações e aos afetos provenientes das experiências sexuais da infância. Desse modo, "o ensejo para o adoecimento apresenta-se à pessoa de disposição histérica quando, em consequência de sua própria maturação progressiva ou das circunstâncias externas de sua vida, as exigências reais do sexo tornam-se algo sério para ela" (Freud, 1996a/1905, p. 156). A relação da histeria com a dificuldade em lidar com o que é inerente à sexualidade foi permitindo considerá-la cada vez mais independente de um sintoma conversivo.

Ao formular sobre os conflitos sexuais vivenciados na histeria, Freud (1996f/1908), afirmava a importância das fantasias bissexuais, indicando a presença de dois impulsos libidinais opostos; um de caráter masculino e outro feminino. Inicialmente, ao abordar o tema, - psicanalista ressaltou que esses aspectos e faz importante e "particularmente indispensável ao entendimento da histeria masculina" (Freud, 1996a/1905, p.64). Os sintomas traduzem os conflitos libidinais dessas fantasias histéricas, sendo o meio pelo qual o sujeito alcança uma satisfação através de um deslocamento. Esse deslocamento, antes atribuído apenas aos sintomas conversivos, passa a ser observado em casos em que "a libido, que tinha sido 
libertada do material patogênico pela repressão, não é convertida (isto é, desviada da esfera mental pela somatização), mas é posta em liberdade na forma de ansiedade [angústia]" (Freud, 1996g/1909, p. 106).

No texto "Análise de uma fobia em um menino de cinco anos" (1909), Freud apresenta a fobia de Hans, enquanto uma histeria de angústia, destacando a angústia como o que é liberado pelo recalque. Quando retoma o caso, no texto "Inibição, sintoma e ansiedade" (1996h/1926), o autor reconhece que tal afeto, na verdade, é a causa do processo de recalque, que envolve a reação diante de uma situação de perigo e, "nos casos que examinamos, o perigo em causa foi o de castração ou de algo remontável à castração" (p. 128).

Em Hans, o objeto externo, o cavalo, nomeia o medo, mas vela o ponto intolerável da angústia. Freud $(1996 \mathrm{~h} / 1926)$ se detém no fato de que o garoto sofria devido à ideia de que um cavalo iria mordê-lo, sugerindo uma possível substituição do pai pelo cavalo, o que permite "um conflito devido à ambivalência ser solucionado sem o auxílio da formação reativa" (p. 105). A referida ambivalência diz da relação de Hans com o pai, que envolvia um "medo de seu pai e medo por seu pai" (Freud, 1996g/1909, p. 47); o primeiro indica sua hostilidade para com ele, já o segundo, evidencia o conflito desta hostilidade com uma afeição exagerada. Com efeito, o menino desiste da agressividade por temor à castração, e o recalque desta hostilidade teria sido reprimido pelo processo de ser transformado em seu oposto; trata-se de um impulso passivo de ser amado pelo pai que, segundo Freud (1996h/1926), "não podemos nem provar que era bastante forte para atrair a repressão sobre si mesmo, nem que desapareceu depois" (p. 109).

A partir do desenvolvimento desses aspectos, na apreensão do Complexo de Édipo e de castração, a histeria vai sendo reconhecida por sua organização libidinal, enquanto modo de defesa frente à castração que se desdobra na fantasia. É nesse âmbito que Freud (1996i/1923) trabalha o caso de Christoph Haizmann, no texto "Uma neurose demoníaca do século XVII". Esse estudo apreende a relação da histeria com a demonologia, baseando-se em um manuscrito que continha relatos da história de um pintor húngaro. $\mathrm{Em}$ sua interpretação, Freud (1996i/1923) relaciona os fenômenos de êxtase à histeria, uma vez que Haizmann teria construído uma fantasia de compromisso com um demônio na tentativa de se libertar do quadro depressivo e melancólico, com intensa inibição para o trabalho, que o abalou após a morte de seu pai.

As interpretações assinalam uma possível relação de ambivalência do jovem pintor com seu pai, uma vez que Haizmann o amava a ponto de avançar em uma depressão após sua morte, mas o representa, em fantasia, pela imagem do demônio. Desse modo, os principais aspectos trabalhados nessa casuística se referem à ambivalência em 
relação ao pai, destacando-se o amor e a inversão do complexo de Édipo como efeito da tentativa de esquiva frente à castração, recolocada na posição feminina decorrente daí.

Os mesmos elementos aparecem no texto "Dostoievski e o parricídio" (1928), no qual Freud $(1996 j / 1928)$ faz considerações sobre o escritor russo Fiódor Dostoievski. O escritor teria perdido a mãe e o pai ainda na juventude, e, a partir da morte do pai, surgem suas crises de epilepsia. Desse modo, mesmo indicando a precariedade das informações, Freud considera que Dostoièvski sofria de uma epilepsia "afetiva", que representava manifestações de crises histéricas ligadas à experiência da morte do pai. Através de um estudo da biografia do escritor, Gomes (2002) assinala que Freud não dispunha de elementos suficientes para refutar o quadro epilético, mas que isso não invalida a hipótese de histeria.

Freud (1996j/1928) localiza nos conflitos de Dostoievski um intenso desejo de morte do pai, interpretado como ambivalente e relacionado ao duplo processo que ocorre na identificação com pai: a admiração e, ao mesmo tempo, o desejo de afastá-lo, remetendo ao obstáculo que se impõe a isso - a castração. Isto haveria de constituir um processo tido como Complexo de Édipo normal, ou positivo, caso o menino, diante do temor à castração, pudesse reprimi-lo ao abandonar o desejo em relação à mãe e, consequentemente, a necessidade de livrar-se do pai. Em Dostoievski o desejo de morte direcionado ao pai aparece como insistente, indicando que algo do temor à castração e da necessidade de distanciamento permaneceu. Esta intensificação patogênica do temor à castração é relacionada à atitude feminina para com o pai, ao tomá-lo como objeto de amor na tentativa de fugir à castração enquanto punição.

O sentimento de autopunição, associado ao desejo da morte do pai, também aparece como elemento da possível histeria em Hamlet, assinalados no texto "A interpretação dos sonhos" (1996k/1900). Nessa leitura, Hamlet não conseguiria vingar-se de Cláudio - homem que matou seu pai e desposou sua mãe -, uma vez que a ação de matar o pai advertia sobre seus próprios desejos recalcados. Para além, Freud ressalta a presença de uma aversão sexual no príncipe dinamarquês, apreendida em sua relação com a jovem Ofélia.

\section{Lacan e a causalidade significante da histeria}

No retorno de Lacan a Freud, a histeria adquire uma causalidade significante, diretamente relacionada ao processo de ascensão da sexualidade. Desse modo, a problemática se daria na dialética do imaginário e do simbólico, em decorrência da ausência de um significante que represente 0 sexo feminino. Isso porque a sexualidade se realiza a partir da simbolização que não se faz 
simetricamente no homem e na mulher, uma vez que, no caso da mulher, "o imaginário fornece apenas uma ausência, ali onde alhures há um símbolo muito prevalente" (Lacan, 2002/1955-56, p. 201). Assim, a necessidade do significante, somada à prevalência da forma imaginária do falo, chamada de "Gestalt fálica", leva a mulher a tomar o caminho da identificação com o pai. Para a histérica o pênis passaria a servir "de instrumento imaginário para apreender o que ela não consegue simbolizar" (Lacan, 1998/1958, p. 203).

A predominância da histeria em mulheres é, então, explicada por tal dissimetria na realização simbólica. E Lacan (2002/1955-56) ressalta que a questão não está relacionada apenas ao "acessório do significante" (p. 202), mas compete à relação do sujeito com o significante em seu conjunto. Logo, o homem também pode ter como saída a posição histérica, revelando a mesma dissimetria em relação ao significante.

Estas proposições são discutidas por Lacan (2002/1955-56) no Seminário 3, As psicoses, quando procura diferenciar a problemática do simbólico e da feminização presente na neurose e as questões sobre procriação no delírio psicótico de Schreber. Faz suas considerações a partir de um caso, atendido pelo psicólogo Michael Joseph Eisler, apontado como histeria traumática. Trata-se da história de um condutor de bonde, de 33 anos, que é arrastado ao cair do veículo, sofrendo ferimentos leves, mas apresentando sintomas persistentes. O problema não se dá em decorrência do acidente, mas dos exames ao qual o homem é submetido. Após as radiografias desencadeiam-se dores nas primeiras costelas e mal estar crescente. O acontecido, associado aos dados da história de vida do condutor e suas queixas, sugeriu que as crises teriam ligação com uma fantasia de gravidez. Os dados de sua história, bem como a fantasia indicam o meio pelo qual o sujeito se utiliza para colocar sua questão: "Será que sou ou não alguém capaz de procriar?" (p. 195).

A partir do caso, Lacan (2002/1955-56) observa que, tal como na mulher histérica, há algo que escapa à trama simbólica no histérico homem que, no caso citado, se apresenta articulado à questão da procriação. Ele está intrigado com o que se passava no interior do corpo onde poderia crescer uma criança. Esse ponto nos remete às considerações de André (1998) a respeito do recalque, em que o autor esclarece que, ao contrário do que Freud acreditava em relação ao recalque e às representações sexuais, a histeria nos revela que o recalque é responsável pela sexualização do corpo, sobretudo, em separação do organismo. Isso indica que a histeria denota uma dificuldade e uma necessidade intensa de defesa frente à sexualidade sem representação. Nas elaborações de Lacan, é a intervenção do significante falo que opera a sexualização do corpo. Mas, na medida em que nem tudo é absorvido pelo significante, na histeria, "é o 
fracasso do recalque que deixa aberta uma hiância por onde se manifesta o trauma" (André, 1998, p. 99).

Além do caso do condutor, Lacan não articula outras casuísticas sobre a histeria em homens com tantos desdobramentos. Mas Bruno (1997) assinala comentário sem que há referência a uma dimensão histérica em outros homens, destacando as menções a Hegel e Sócrates. O psicanalista francês também trabalha amplamente o caso de Hans, mas não explicita o diagnóstico de histeria para o garoto. Precisamente, Lacan (1995/1956-57) diz que "ele [Hans] não faz uma histeria e sim uma fobia." (p. 290). Contudo, em um momento posterior de seu ensino, Lacan (2008/1968-69) conclui que a fobia não deve ser apreendida enquanto uma entidade clínica, mas "como uma placa giratória. Ela gira mais comumente para as duas grandes ordens da neurose, a histeria e a neurose obsessiva, e também faz a junção com a estrutura da perversão." (p. 298). Essa proposição permite retomarmos as articulações do autor com base no diagnóstico apontado por Freud (1996g/1909).

O mesmo se passa com as considerações sobre Hamlet, que se apresenta como o lugar do desejo e, por ser uma criação poética, pode representar elementos tanto da neurose histérica quanto da neurose obsessiva. Todavia mobiliza algo do desejo histérico enquanto um desejo que "está ali sem que o sujeito saiba e, portanto, ele é forçado a construí-lo" (Lacan, 2016/1958-59, p. 312), ou seja, na medida em que seu problema consiste em reencontrar 0 lugar de seu desejo e, mais ainda, quando cria para si um desejo insatisfeito e conflitante ao esbarrar com a questão do desejo do Outro materno.

Os dois casos veiculam elementos que se aproximam, conforme as articulações de André (1998), no que tange a posição de angústia na qual o sujeito está completamente submetido ao Outro. É na relação infantil de cuidado materno que temos a situação que funda a experiência traumática do sujeito neurótico, uma vez que aí ele é tomado como objeto e instrumento do gozo do Outro. Mais precisamente, a maneira como o sujeito lida com essa experiência primária de passividade, a forma como ela é "retomada, remanejada na fantasia e relembrada no recalque e retorno do recalcado vai determinar a escolha da neurose" (André, 1998, p. 88). Na histeria, "o esquema do recalque permanece paralelo ao sentido do trauma: o insuportável é a posição passiva, a posição de objeto entregue ao gozo do Outro" (p. 88). Nesse sentido, Lacan (1999/1957-58) aponta que o histérico "é o sujeito para quem é difícil estabelecer com a constituição do Outro como grande Outro, portador do signo falado, uma relação que the permita preservar seu lugar de sujeito" (p. 376). É no contexto dessa discussão que Lacan (1995/1956-57) trata as questões sobre a fobia no caso do pequeno Hans, para quem a angústia era, essencialmente, a angústia de assujeitamento. 


\section{O homem histérico e a problemática da posição sexual: Quais os impasses?}

No percurso de Freud a sexualidade se articula, além de outras vicissitudes, à satisfação pulsional - ativa e/ou passiva - e ao resultado do processo identificatório do complexo de Édipo. Para Lacan (1998/1958), a dimensão de atividade e passividade encontra sentido a partir da inscrição fálica, em que o falo surge como regulador da organização libidinal infantil e implica os complexos de Édipo e de castração. A sexuação em relação ao falo, a qual produz uma posição do sujeito em relação ao desejo, denota o ter do lado masculino e o ser do lado feminino.

Se o menino passa pela situação edipiana em conformidade com certa normatização, na idade adulta, na relação simbólica, se verá investido do falo como tal, reconhecendo-se como portador do objeto do desejo para aquele objeto que irá suceder o objeto materno, ou seja, a mulher (Lacan, 1995/1956-57, p. 83). Mas, quando algo não se cumpre completamente na identificação metafórica à imagem do pai, e Lacan (1999/1957-58/) diz que jamais é realizado completamente, ao se deparar com a castração, o menino terá dificuldades em ocupar o lugar e a função viril. Isso considerando que a função típica do Édipo implica que não basta ser heterossexual, ou seja, ter uma escolha de objeto heterossexual, pois nisto pode se "ocultar, ocasionalmente, uma atipia posicional que a investigação analítica vai nos mostrar ser derivada, por exemplo, de uma posição francamente homossexualizada" (Lacan, 1995/1956-57, p. 25). É preciso que o sujeito se situe com referência à função do pai. Veremos o que acontece na histeria masculina.

\section{Uma renúncia não decidida}

No texto "Sexualidade feminina", em articulações sobre a histeria em mulheres, Freud (1996I/1931) havia relacionado aspectos da etiologia de tal neurose à fase de dependência e ligação primordial do sujeito com a mãe. Lacan (1995/1956-57) pontuou algo dessa excessiva aproximação no caso Hans, sobretudo, enquanto uma relação essencial com o desejo materno. O mesmo desejo insaciável e marcado pela busca de algo que possa saciá-lo é um dos aspectos que atormenta e sobredetermina o impasse de Hamlet em executar o ato que lhe cabe (Lacan, 2016/1958-59).

0 caso Hans nos permite entrever que, ainda que o garoto tenha decaído da posição de ser o falo imaginário que falta ao Outro, restaram ambiguidades contundentes em relação ao capricho do Outro materno e uma aterrorizante angústia de não ter quem lhe respondesse pelo que há de traumático no desejo do Outro. Como 
efeito, tal como Hamlet, resta um sujeito muito mais confrontado com o desejo da mãe do que por um desejo pela mãe (Lacan, 2016/1958-59), e, portanto, vacilante em permanecer ou não identificado ao falo materno. Na verdade, os dois casos sugerem que há um conflito fundamental entre o desejo de se separar da mãe e o de confundir-se com ela.

O que pôde acontecer em termos de quebra na relação imaginária de Hans com sua mãe, se deu a partir do momento em que intervém a pulsão, o pênis real. Momento em que a criança é "confrontada com a hiância imensa que existe entre satisfazer sua imagem e ter algo de real para apresentar" (Lacan, 1995/1956-57, p. 232). Lacan coloca como decisivo o fato do que é oferecido pela criança aparecer como miserável. Assim, o pênis fica à margem, como algo que nunca foi senão maldito, reprovado pela mãe, a qual faliciza, não o pênis, mas Hans em sua totalidade (Miller, 1995).

Contudo, mesmo tendo sido confrontado com isso que não permite integrar a sua imagem fálica, não há como fazer o envio da hiância aberta na relação com a mãe para o pai, por onde ele poderia situarse em outra dimensão do falo. Eis a lógica da estrutura histérica para Dör (1991), que se dá neste reviramento da dialética do ser ao ter, nesse "'passo a dar' na assunção da conquista do falo" (p. 65).

Nesse contexto, a configuração que leva o sujeito a manter certa identificação fálica, tem como decisivo a relação difícil da mãe com sua própria castração, bem como a maneira como se apresenta a função paterna, pois a investidura fálica do pai poderia retirar o menino desse conflito, já que na função paterna está em jogo a significação fálica, ou seja, a introdução do Nome-do-pai que produz uma significação ao desejo da mãe. Com efeito, o importante na constatação disso que resta de uma identificação ao falo materno e, também, da incidência perturbadora que resta do desejo do Outro, é que a dificuldade em renunciar decididamente e efetivamente a ser 0 falo implicará em um sacrifício da posição viril para o histérico. A posição de ser permite a aproximação com o signo do que é desejado, além de tapear a verdade sobre a falta de objeto. Mas acontece que não é a mesma coisa, sobretudo para a sexualidade masculina, manter o falo como aquilo que reforça uma imagem fálica e mantê-lo como atributo viril, a partir da identificação significante com o pai.

Não obstante, há uma coisa que não é sem importância; a presença do pênis exige do menino todo um movimento em favor de preserválo, sobretudo quando constata que pode perdê-lo. Na histeria, a confusão em relação à perda desse objeto é balizada pelo auge do complexo de castração que, segundo Nasio (1991), relaciona-se a uma experiência visual da ausência do pênis na mulher que domina a fantasia e a angústia do histérico. Com isso, as questões que se impõem sobre o enigma da presença ou ausência do falo, se 
articulam com o desconhecimento do tipo de laço que sustenta a união dos pais.

A solução que o homem histérico parece encontrar como tentativa de preservar-se é a escolha de outro caminho com o qual não tenha que se haver com a castração. Aqui, a posição masculina ou ativa, que até então era expressa pelas tentativas do menino de possuir a mãe, se torna intimidada. $O$ menino abandona a agressividade para com 0 pai e se direciona a ele enquanto objeto de amor. Logo, esta aproximação não acontece pela via em que o pai confere valor ao falo. Na verdade, a tentativa de evitar a castração do histérico é também correlativa a essa falha da função paterna. Para além, na relação do histérico com a figura materna irá sobressair a relação especular, o que podemos articular à proposição de Freud (1996d/1888) sobre a identificação regressiva, que se dá como resultado de uma relação de amor, na medida em que o objeto decepciona no apelo a esse afeto.

\section{O amor ao pai e a fantasia de feminização}

Quando Freud (1996I/1931) pontua, a respeito da histeria em mulheres, uma intensa relação de amor para com a mãe, sugere que, tendo que se desvencilhar desse amor, o sujeito tem como refúgio ou compensação, uma profunda ligação com o pai; é dele que se espera ser amado. Essa transferência é indicada no caso de Haizmann, a partir da representação do diabo com mamas, em que Freud (1996i/1923) sugere o deslocamento de uma relação inicial de apego à mãe para o pai. Eis a questão do amor ao pai, identificado em casos de histeria como o que impacta o atravessamento do Édipo. E, se a mulher histérica se atém a esse amor por esperar que o pai possa dar o que, supostamente e imaginariamente, Ihe falta, o homem histérico busca no amor ao pai, enquanto uma compensação pela intensidade do ódio dada à ligação com a mãe, a proteção contra a castração.

Entretanto, ao querer evitar a castração "recusando ser o rival do pai, vai encontrar novamente a castração ao querer ser o objeto de amor do pai... Aí está, verdadeiramente, o cerne da histeria masculina" (Bruno, 1997, p. 141). O que parecia ser uma saída vantajosa não elimina o temor da castração, uma vez que "fazer-se amar por ele [pai] consiste em passar, primeiramente, para a categoria de mulher" (Lacan, 1999/1957-58, p. 177), que também comporta o perigo da castração. $O$ resultado denota uma intensificação da angústia, pois, segundo Freud $(1996 \mathrm{j} / 1928 ; 1996 \mathrm{i} / 1923)$, o temor e a revolta contra a castração, enquanto punição, intensifica-se de forma patogênica com o acréscimo do temor à atitude feminina em relação ao pai. Ou seja, a angústia é redobrada na posição feminina, que não pode 
fornecer a proteção procurada, tornando-se a mais preponderante (Bruno, 1997).

A dimensão do Édipo invertido, articulada às implicações do recalque na histeria, tem como efeito um impasse subjetivo frente à posição sexual do homem histérico, uma vez que, se por um lado tem-se o retorno das tendências pulsionais afetuosas, por outro, há "sua suspensão, isto é, seu recalque, em razão da ameaça de castração que essa posição comporta" (Lacan, 1999/1957-58, p. 177). E, de acordo com Nasio (2007), se o encontro com a ameaça de castração pelo Édipo positivo incide sobre o Falo-pênis, no Édipo invertido sobrevém em relação ao Falo-virilidade. No segundo caso, a fantasia do menino apreende o agente da ameaça como um "pai sedutor", o qual se teme ir longe demais.

Nesse sentido, o homem histérico se diferencia em sua fantasia, na medida em que, enquanto o obsessivo promove o pai como significante ideal, rivalizando e se potencializando diante dele, no histérico "temos um fantasma que coloca em cena, não a potência do filho diante do pai morto, mas a feminização do filho em relação ao pai" (Bruno, 1997, p. 145). A respeito disso, Gomes (2002) ressalta a intensa submissão de Dostoiévski à figura paterna do czar, revelada na aceitação de uma condenação injusta imposta por ele.

Considerando essa relação particular do histérico com o pai, Pierre Bruno (1997) salienta: ainda que o sujeito não seja efeito de uma determinação, há referências clínicas na forma como se apresenta, ou é apreendida, a função paterna para o histérico que não devem ser rejeitadas. Em sua leitura, o autor destaca a preponderância do que Lacan (1995/1956-57) formulou como pai real, enquanto aquele que promove a castração, em relação à operação do pai simbólico, que não figuraria enquanto suporte da Lei à qual é submetido. Contudo, a figura do pai real, aqui tomada em sua relação com o pai onipotente, o qual não teria "conflito com sua virilidade" (p. 145), sugere muito mais uma imaginarização do sujeito do que a efetiva operação do pai real.

Teixeira (1997) esclarece esse ponto ao retomar, do início, a figura do pai que "não comparece para privar a mãe do falo imaginário ao qual o filho se identifica, restando para o sujeito a insuficiência do pai em manter as promessas do desejo" (p.10). A autora pontua que essa ausência denota para o sujeito a implicação do pai com o próprio gozo, e é nisso que se localiza a dupla dimensão do pai na histeria, que vai da impotência à imagem indiscutível e terrificante. Trata-se de "uma cobertura imaginária que o sujeito histérico sustenta no registro da proteção ao pai. Para encobrir o fracasso do pai em barrar o gozo da mãe, o histérico recua frente à castração imaginarizando um pai de pura potência" (Teixeira, 1997, p. 13).

De acordo com a interpretação de Gomes (2002), o pecado do pai carrega a dimensão do seu desejo, o que vem a ser insuportável por 
colocar à mostra a posição de objeto ocupada pelo sujeito frente a esse desejo. Por portar referência ao elemento pulsional, o desejo do pai suscita a angústia e o amor a ele encobre a face inconsistente desse sujeito desejante. Faz desse amor ao pai um álibi para "não se deparar com a sua falha, com o ponto em que o sentido falta e aparece o injustificado da existência" (Gomes, 2002, p. 107).

Essa condição do sujeito histérico sugere a posição de um pai que nem sempre surge como um pai que proíbe, mas nunca se apresenta como um pai que protege; é o amor ao pai que toma o papel de proteção contra a angústia, velando a inconsistência do Outro e impedindo o confronto com o desamparo irredutível do sujeito. Mas, ao tentar velar a inconsistência desse pai através do amor, o homem histérico paga o preço de se manter paralisado em uma posição de assujeitamento, sem poder avançar em direção ao desejo, evidenciando uma submissão à vontade do Outro como resposta a essa exigência de restaurar a figura paterna toda-poderosa. Como consequência, há um prejuízo na identificação simbólica em favor de uma "identificação maciça à falha do pai", em que "o sujeito anula o uso da significação fálica, desdenhando o gozo fálico pela inibição" (Teixeira, 1997, p.14).

\section{A relação com o falo simbólico}

As articulações realizadas até aqui revelam que, para o histérico, o aspecto simbólico da função paterna está submetido ao que, sobretudo, se potencializa com a imaginarização do pai real. Nesse sentido, sabemos que o fracasso da referência ao pai simbólico, no contexto da teoria do Édipo, coloca em risco a função da metáfora paterna, comprometendo, portanto, a castração simbólica. No entanto, a inscrição do Nome-do-Pai, segundo Lacan (1998/1958), se faz perfeitamente possível existir mesmo com a falha na operação do pai real. Relativo a isso, no caso Hans, essa função pôde ser feita por um elemento diferente daquele que se refere ao pai da realidade. Conforme ressalta Miller (1995), nesse caso, "o Nome-do-Pai, tornase muito difícil colocá-lo, em toda a sua autoridade, no pai real" ( $p$. 73). Todavia,

o desvio da metaforização que deveria, em outras condições, ser operada pelo pai real só dificulta a desimaginarização desse Outro. Enquanto idealizado, este último encontra-se inflado pela imagem não-negativizada do falo materno, cuja consequência para o sujeito é um apego à sua resposta fantasmática. (Miller, 1995, p. 21) 
Para Lacan (1999/1957-58), o pai real, enquanto aquele que dá corpo à castração, ao intervir efetivamente na relação da criança com a mãe, daria subsídios para o que seria uma efetiva identificação simbólica. Essa identificação viria sobrepor à totalidade enganosa do imaginário, permitindo situar o falo em uma linhagem paterna. O que Bruno (1997) demarca como defeito na identificação simbólica do homem histérico exprime, então, a dificuldade com a transmissão do falo, implicada na relação com a castração, a qual comanda a sexuação.

Nessa falha da identificação simbólica está a explicação de Lacan (2002/1955-56) no tocante à fantasia de gravidez do condutor de bonde, que exprime a questão com a sustentação da função viril que, para o paciente de Eisler, envolvia a função de pai com a qual estaria lidando no período do acidente. A questão do condutor teria como fundamento saber se ele era ou não capaz de procriar, que remete, também, à possibilidade de exercer a função paterna, a qual foge à trama simbólica do histérico (Bruno, 1997).

É por meio do significante que o sujeito se reconhece e tem acesso, por exemplo, à função paterna. Significante apreendido, inicialmente, em sua forma imaginária, a qual o macho exibe sob o que Lacan (2002/1955-56) chama de material significante, porém precisa simbolizá-lo, afinal, "é pela simbolização a que é submetida, como uma exigência essencial, a realização genital - que o homem se viriliza, que a mulher aceita verdadeiramente sua função feminina" (p. 203). Nisso se destacam as articulações sobre a histeria em relação à dissimetria edípica, no que tange a problemática com o significante.

Para que seja possível a transmissão do falo simbólico, é necessário que a castração se efetive a partir da interdição do pai, possibilitando que "o órgão assim erogeneizado tome o lugar de função negativização do falo imaginário que produz a positivação do falo como símbolo de uma falta" (Teixeira, 1997, p. 10). Na histeria, a relação com a castração é marcada pela insuficiência do testemunho parental, que implica na carência da significação fálica do órgão.

Em Hans, Lacan (1995/1956-57) pontua que a problemática recai em saber como o menino "vai poder suportar seu pênis real" (p. 375). No final, a despeito de toda organização e formulação que foi possível ao menino, "o pênis real consegue se alojar de uma maneira suficiente para que o pequeno Hans possa prosseguir sua vida sem angústia. [Mas] disse suficiente e não necessária, porque ela poderia ser ainda mais plena" (Lacan, 1995/1956-57, p. 283). Para o psicanalista, ainda que o garoto se mostre em conformidade com a ordem sexual, pois é um menino que se interessa por meninas, não ocupa tal posição de modo viril.

A dificuldade com a referência simbólica do falo nos leva a pensar nos efeitos sob a posição desse sujeito, no que compete à relação sexual, 
na dimensão do desejo e da fantasia. Isso considerando que, conforme Lacan (2016/1958-59), o desejo figuraria como modo de articular a falta a um objeto na fantasia. Na dinâmica do desejo masculino, o homem coloca a mulher, fantasiosamente, na posição do falo que Ihe falta, ou seja, daquilo que ele está privado simbolicamente. Acontece que, na fantasia histérica, a qual se relaciona com o desejo, o histérico, ao invés de ocupar o lugar de sujeito, busca identificar-se com o objeto do desejo (a) do Outro, esforçando-se para ocultar a castração $(-\varphi)$ desse Outro $(A)$ e a sua própria.

Com efeito, na lógica do sujeito histérico ter o falo seria, na realidade, sê-lo (Nasio, 1991). Essa confusão do histérico em relação à dinâmica do falo se expressa na inibição da sexualidade genital em compensação a um maior investimento do corpo não-genital que é falicizado e erotizado. $E$, se a conversão histérica denota uma tentativa de sexualização daquilo que escapa ao recalque (André, 1998), a falicização do corpo histérico também surge como meio de erotização e sexualização. Logo, a ênfase pode se desvelar na sedução como suporte privilegiado do histérico homem na negociação de amor (Dör, 1991), evidenciando que, na dinâmica do desejo, o sujeito está interessado mais na relação desejante do que no próprio objeto (Lacan, 1999/1957-58, p. 337).

Assim, a partir do que se revela na formulação da fantasia histérica, para o homem histérico, a mulher figura ao nível do Outro, sendo idealizada e colocada, fantasmaticamente, como um objeto que the permite orientar-se quanto à atribuição fálica ao mantê-la em um pedestal, como um objeto precioso para valorizar e exibir ao outro (Dör, 1991). Entretanto, esta mulher nunca deve transgredir esta função, pois o pedestal é onde a economia libidinal do histérico pode se acomodar melhor. Caso esta mulher se apresente como desejante, passa a convocar o histérico a dar provas de sua virilidade, ou seja, a justificar ter o falo que ela demanda. Assim, afigura feminina transforma-se em um objeto preocupante, que põe à prova a atribuição fálica, evidenciando que "ele próprio [o histérico] se desacredita, de antemão e sem sabê-lo, por causa da posição sintomática que é a sua face ao falo" (Dör, 1991, p. 127).

Nesse sentido, certa ânsia por reconhecimento, articulada à imagem, pode figurar como uma tentativa do histérico expressar algo de uma posição fálica, mas, de certo, acaba por revelar sua inconsistência, pois "nenhuma virilidade pode ser sustentada, mesmo com o suporte de uma imagem fálica, fora da referência simbólica do falo" (Oliveira 1997, p. 20). Nessa dinâmica, o histérico expressa os efeitos do fracasso da referência simbólica do falo que possibilitaria amparar um processo identificatório. Diversas tentativas, como o uso de álcool, surgem enquanto meio de assegurar uma nota compensatória em seu ser masculino (Dör, 1991), isso considerando que o álcool reduz as 
inibições e é associado à virilidade. Ao mesmo tempo, no uso desse recurso, o histérico evidencia a dificuldade com a posição masculina, já que o álcool pode impedi-lo de se posicionar sexualmente como homem.

Com tais conjecturas, entendemos que é a insuficiência referente à operação do pai real que prepondera em relação à função do pai simbólico. Assim, como Miller (1995) pontua a respeito de Hans, a função paterna na histeria masculina implica a ideia de um pai real que não transmite a operação Nome-do-pai, revelando um prejuízo em sua constituição. E, segundo André (1998), é no destino feminino que "o pai não se impõe verdadeiramente como metáfora" (p. 181), já que a introdução na lei do falo se faz insuficiente para designar aquilo que seria a feminilidade (André, 1998). Se para a menina essa limitação confere uma insuficiência do significante falo em atribuir o seu lugar de mulher, para o menino é o alcance dessa metáfora que possibilitaria ocupar uma identificação masculina, ainda que a significação induzida nunca seja completa.

Para o histérico, o pai real está posto apenas como potencial agente da castração, que acaba recaindo sobre uma figura imaginarizada pelos seus sintomas, que não cumpre efetivamente uma intervenção. Ou seja, a maneira como se apresenta o pai real na histeria masculina não permite inscrevê-lo na condição de morto, enquanto uma exceção, impossibilitando que este faça cumprir a função naquilo que o compete; dar corpo à castração. Sendo assim, podemos entender que a carência ou a impotência do pai na histeria está para além do que se refere a uma falha ou um enfraquecimento da lei, "mas a uma demissão do pai real com relação ao desejo da mãe, ou seja, junto a uma mulher que ele não ousa encontrar ou confrontar como mulher" (Zenoni, 2007, p. 20). Dessa falha do pai real, resta a carência de uma regulação externa ao desejo do Outro materno, evidenciando, "em modalidades diversas, uma dissociação entre a dimensão da lei e a dimensão do desejo... [e] a identificação ao falo cria uma dificuldade no encontro, especificamente, com o outro sexo" (Zenoni, 2007, p. 20).

\section{Considerações finais}

Estas articulações nos permitem compreender a que se refere Nasio (1991) quando diz que "o histérico é histérico por não ter conseguido tornar seu o sexo de seu corpo" (p.123). O desamparo consequente da vacilação subjetiva em relação à posição sexual expressa os efeitos do fracasso com a referência simbólica que possibilitaria amparar um processo identificatório, afetando o homem histérico naquilo que se refere a sua identidade sexual. Assim, os traços de feminização que decorrem daí podem ser vistos, conforme Menard 
(2015), enquanto "testemunho de um efeito do significante no interior de uma problemática edipiana" (p. 5), que tem como fundamento a resistência à castração correlativa ao fracasso do pai real, no que se expressa um assujeitamento ao falo materno e a passividade como valor da pulsão. Esse efeito tem consequências, tal como aponta Dunker (2018), que se exprimem nas formas responsivas aos fatores culturais. Nesse âmbito, o histérico se revela enquanto um homem dividido, muitas vezes em conflito e alienado ao que o outro espera dele, evidenciando a necessidade de reconhecimento e uma tendência ao fracasso. Tais aspectos contrariam o que, sobretudo nas expectativas sociais, designa o papel masculino e configura a masculinidade, ou seja, o indivíduo que se autonomiza, se torna independente do outro, que tem vontade determinante e não se abala com o desejo do outro (Dunker, 2018). Certamente a cultura não define o padecimento do sujeito, mas é importante ser considerada, uma vez que essa demanda externa se articula à organização da singularidade do sujeito.

De certo, a temática exige discernir aquilo que se refere ao conflito com as representações sociais da masculinidade do que concerne aos aspectos fundamentais que, para a psicanálise, dimensionam a relação do sujeito com a sexualidade masculina. Nesse ponto, este percurso permite entrever alguns desafios para a clínica diante dos entraves vivenciados pelo homem na histeria, a saber: a necessária regulação pela castração e pelo falo simbólico para a sexualidade masculina. Se na clínica da histeria com mulheres a direção do tratamento pressupõe, além de fazer operar a castração, que 0 sujeito se instale em uma posição, dita feminina, que, inclusive, nas elaborações posteriores da psicanálise, vai além da referência do falo, como poderíamos pensar a condução do tratamento diante do que a histeria masculina nos impõe? Considerando que se trata de um homem em que a dificuldade com a referência simbólica do falo torna-se um embaraço na relação com a sexualidade masculina.

Para além de todo trabalho analítico que as questões acima demandam, se o caráter neurótico da questão histérica, tal como afirma Safatle (2016), se encontra na impossibilidade de o sujeito suportar a ausência de uma resposta decisiva que lhe colocaria em uma posição assegurada, é ao atravessar a prova da angústia e da castração que a feminilidade, a qual o histérico repele com horror, se transforma no assentimento daquilo que Nasio (1991) designa como o lado feminino do homem, a partir do que ele "aceita manter seu ser sexuado como um enigma que reaviva e anima o desejo" (p.131). 


\section{Referências}

André, S. (1998). O que quer uma mulher? Rio de Janeiro: Jorge Zahar.

Bruno, P. (1986). 1886-1986: La histeria masculina (M. Mendez, Trad.). In Fundación del Campo Freudiano em Argentina, Histeria Y Obsesion. Buenos Aires: Manantial.

Bruno, P. (1997). A histeria masculina. Revista Curinga, (9), 138145.

Dör, J. (1991). Estruturas e clínica psicanalítica. Rio de Janeiro: Livraria Taurus-Timbre Editores.

Dunker, C. I. L. (2018, Abril 29). Como a histeria se manifesta no homem [Arquivo de vídeo]. Recuperado de https://www.youtube.com/watch?v=IW47uN7V3IM

Freud, S. (1996a). Três ensaios sobre a teoria da sexualidade. In J. Salomão (Trad.), Edição Standard Brasileira das Obras Psicológicas Completas de Sigmund Freud (Vol. 7, pp. 117218). Rio de Janeiro: Imago. (Obra original publicada em 1905)

Freud, S. (1996b). Um estudo autobiográfico. In J. Salomão (Trad.), Edição Standard Brasileira das Obras Psicológicas Completas de Sigmund Freud (Vol. 20, pp. 11-78). Rio de Janeiro: Imago. (Obra original publicada em 1925)

Freud, S. (1996c). Observação de um caso grave de hemianestesia em um homem histérico. In J. Salomão (Trad.), Edição Standard Brasileira das Obras Psicológicas Completas de Sigmund Freud (Vol.1, pp. 61-67). Rio de Janeiro: Imago. (Original publicada em 1886)

Freud, S. (1996d). Histeria. In J. Salomão (Trad.), Edição Standard Brasileira das Obras Psicológicas Completas de Sigmund Freud (Vol. 1, pp. 75-94). Rio de Janeiro: Imago. (Obra original publicada em 1888)

Freud, S. (1996e). A hereditariedade e a etiologia das neuroses. In J. Salomão (Trad.), Edição Standard Brasileira das Obras Psicológicas Completas de Sigmund Freud (Vol. 3, pp. 141155). Rio de Janeiro: Imago. (Trabalho original publicado em 1896)

Freud, S. (1996f). Fantasias histéricas e sua relação com a bissexualidade. In J. Salomão (Trad.), Edição Standard Brasileira das Obras Psicológicas Completas de Sigmund Freud (Vol. 9, pp.147-154). Rio de Janeiro: Imago. (Obra original publicada em 1908)

Freud, S. (1996g). Análise de uma fobia em um menino de cinco anos. In J. Salomão (Trad.), Edição Standard Brasileira das Obras Psicológicas Completas de Sigmund Freud (Vol. 10, pp. 15-133). Rio de Janeiro: Imago. (Obra original publicada em 1909) 
Freud, S. (1996h). Inibição, sintoma e ansiedade. In J. Salomão (Trad.). Edição Standard Brasileira das Obras Psicológicas Completas de Sigmund Freud. (Vol. 20, pp. 81-171). Rio de Janeiro: Imago. (Obra original publicada em 1926)

Freud, S. (1996i). Uma neurose demoníaca do século XVII. In J. Salomão (Trad.), Edição Standard Brasileira das Obras Psicológicas Completas de Sigmund Freud (Vol. 19, pp. 83120). Rio de Janeiro: Imago. (Obra original publicada em 1923)

Freud, S. (1996j). Dostoievski e o parricídio. In J. Salomão (Trad.), Edição Standard Brasileira das Obras Psicológicas Completas de Sigmund Freud (Vol. 21, pp. 183-200). Rio de Janeiro: Imago. (Obra original publicada em 1928)

Freud, S. (1996k). O material e as fontes do sonho. In J. Salomão (Trad.), Edição Standard Brasileira das Obras Psicológicas Completas de Sigmund Freud (Vol. 4, Cap. 5, pp. 195-302). Rio de Janeiro: Imago. (Obra original publicada em 1900)

Freud, S. (1996l). Sexualidade feminina. In J. Salomão (Trad.), Edição Standard Brasileira das Obras Psicológicas Completas de Sigmund Freud (Vol. 21). Rio de Janeiro: Imago. (Obra original publicada em 1931)

Gomes, R. M. de M. (2002). O amor que encobre a falha paterna: dos impasses na teoria freudiana do pai (Dissertação de mestrado). Universidade Federal de Minas Gerais, Belo Horizonte, MG, Brasil.

Lacan, J. (1995). O seminário, livro 4: a relação de objeto (D. Estrada, Trad.). Rio de Janeiro: Jorge Zahar. (Obra original proferida em 1956-57)

Lacan, J. (1998). A significação do falo. In Lacan J., Escritos (R. Vera, Trad.). Rio de Janeiro: Zahar. (Obra original publicada em 1958)

Lacan, J. (1999). O seminário, livro 5: as formações do inconsciente (R. Vera, Trad.). Rio de Janeiro: Jorge Zahar. (Obra original proferida em 1957-58)

Lacan, J. (2002). O seminário, livro 3: as psicoses (A. Menezes, Trad.). Rio de Janeiro: Jorge Zahar. (Obra original proferida em 1955-56)

Lacan, J. (2007). Considerações sobre a histeria. In Miller (Ed.), Opção Lacaniana, no 50. Rio de Janeiro: Jorge Zahar. (Obra original publicada em 1977)

Lacan, J. (2008). O seminário: Livro 16: De um Outro ao outro. Rio de Janeiro: Jorge Zahar. (Obra original proferida em 1968-69)

Lacan, J. (2016). O seminário, livro 6: o desejo e sua interpretação (C. Berliner, Trad.). Rio de Janeiro: Jorge Zahar. (Obra original proferida em 1958-59)

Menard, A. (2015). Da histeria masculina ao "empuxo-à-mulher" da psicose. Clínica diferencial da histeria e da psicose. Opção 
Lacaniana online, 6(17), 1-10, Recuperado de http://www.opcaolacaniana.com.br/pdf/numero_17/Da_histeria masculina.pdf

Miller, J. A. (1995). A lógica na direção da cura. Minas Gerais: Seção Minas Gerais da Escola Brasileira de Psicanálise do Campo Freudiano.

Nasio, J. D. (1991). Histeria: Teoria e clínica psicanalítica. Rio de Janeiro: Jorge Zahar.

Nasio, J. D. (2007). Édipo: o complexo do qual nenhuma criança escapa. Rio de Janeiro: Jorge Zahar.

Oliveira, S. M. E. (1997). Histeria masculina: Um "empuxo-aTirésias". Revista Curinga, (9), 18-21.

Safatle, V. (2016). Permanecer histérica: Sexualidade e contingência a partir do caso Dora. Ágora: Estudos em Teoria Psicanalítica, 19(3), 377-392. doi:10.1590/S1516-14982016003003

Teixeira, M. C. (1997). Em nome do pai, a virilidade danificada por efeito do fracasso da função do pai real. Curinga, 1, 7-14.

Zenoni, A. (2007). Versões do Pai na psicanálise lacaniana: O percurso do ensinamento de Lacan sobre a questão do pai. Psicologia em Revista, 13(1), 15-26. Recuperado de http://pepsic.bvsalud.org/scielo.php?script=sci_arttext\&pid=S1 677-11682007000100002

\section{Endereço para correspondência}

Jéssica Fernanda Matias

Rua Dom Bosco, 392, CEP 32235-050, Contagem - MG, Brasil

Endereço eletrônico: jessicaf.m@hotmail.com

Recebido em: 01/02/2019

Aceito em: 06/06/2019

\section{Notas}

* Psicóloga pela Pontifícia Universidade Católica / PUC-Minas (2014). Mestranda na Universidade Federal de Minas Gerais / UFMG (02/2017-02/2019).

Financiamento: Universidade Federal de Minas Gerais, CNPq.

Este artigo de revista Estudos e Pesquisas em Psicologia é licenciado sob uma Licença Creative Commons Atribuição-Não Comercial 3.0 Não Adaptada. 